IRSH 47 (2002), pp. 465-485 DOI: I0.1017/S0020859002000743

(C) 2002 Internationaal Instituut voor Sociale Geschiedenis

\title{
The Challenge of Strategy: A Comment
}

\author{
JAN K OK
}

Is "strategy" merely a sympathetic and convenient phrase, on closer scrutiny devoid of explanatory value as a scientific concept? Have we been beguiled by its appeal and should we now, wiser and sadder, return to less pretentious concepts such as tactics or agency? Or do we need more empirical applications and have we just begun to explore strategy's vistas?

In the preceding articles, the highly popular concept of "family strategy" is being strongly criticized. The authors grant it a certain usefulness, in the sense that it has been helpful in breaking down the structuralist paradigm and in restoring individual actors to their rightful place in historical analysis. Also, they readily admit that the concept has a strong appeal in promising a way of combining individual motives and actions with the constraints set by the economic, demographic, or legal environment. However, strategy has lost much, if not all, of its allure for Lynch, Viazzo, and Engelen. Engelen concludes straightforwardly: "I see no function for it any more". Lynch and Viazzo are only slightly less sceptical. They berate the present use of the concept for its "alarming degree of looseness and confusion" and advise against adding more empirical cases. Still, they advocate a "reassessment of both the potentialities and the limitations of the notion". However, their contribution is devoted mainly to the latter, the limitations of the strategy concept. In their conclusion, Lynch and Viazzo state that only "direct or extremely strong indirect evidence" can be accepted to prove the existence of strategies. They also feel that "strategies" suggest a capacity to make long-term plans which most people in the past lacked. Therefore, they advocate the much less pretentious term "tactics" to denote short-term adaptations to changing circumstances. Finally, they argue that the concept should distinguish between those who make and those who are affected by strategies. The authors do not elaborate how this redefined, limited version of the strategy concept can be set to work in empirical studies. Instead, they plead for a qualitative analysis of the meaning of "family" to historical actors, "sorted by age, gender, class, or even individual sensibility". Engelen, on the other hand, seems to be content with revealing and describing "informative statistical trends indicating how in certain historical periods certain social groups in certain circumstances tended to act".

Although I share some of the concerns voiced by Engelen, Lynch, and 
Viazzo, I do not agree that historical research is served by restricting the use of the strategy concept. On the contrary, I would like to argue that a continued elaboration and empirical testing of the concept is one of the great challenges for the future. I will substantiate this by showing that the strategy concept - to be understood as an hypothesis regarding the nature of human action - is both theoretically sound as well as perfectly applicable in empirical research. According to Engelen, one of the main problems with the concept is that it tends to overestimate the rational choice of individuals versus behaviour stemming from tradition or societal norms. These norms may serve a macro-level logic, of which the individuals themselves were not aware. The fallacies in this line of reasoning will be discussed in the next section, which is titled Systems, Traditions and Rational Actors. As an illustration, I will enlarge on the subject of pre-modern proletarian fertility, one of the fields Lynch and Viazzo believe to be beyond the range of conscious planning. In both papers it is repeatedly emphasized that it is a methodological error to infer strategic intentions from behavioural outcomes. In the third section, I will try to show that, by using appropriate sources and techniques, it is possible to determine the strategic content of past behaviour. Another issue raised in both articles is related to the family as a decision-making unit. Can we conceive of "family strategies" in the face of differing positions and interests of the sexes and generations within the family? I agree with Lynch and Viazzo that our analyses should recognize the possible tensions between strategies of daughters, sons, mothers, and fathers. Based on recent research on leaving home and domestic service, the fourth section will demonstrate the feasibility of such an approach. As has been mentioned above, Lynch and Viazzo believe that most human action in the past had better be captured in the term "tactics", thereby reserving "strategy" for conscious planning for the longer term. In the section titled The Scope of Strategy, I will argue that instead of relegating them to separate categories, we should study short- and long-term strategies simultaneously, and show how they interacted. By changing their "coping repertoires", people influenced both their own environment as well as society at large.

Before elaborating on these subjects, a few words on definition are apposite. Lynch and Viazzo have a point when they lament that the strategy concept is "ambiguous and ill-defined". For the time being, a common-sense notion of strategy will serve as a suitable point of departure. Let us go back to Fredrik Barth, who first coined the term "strategy" in social anthropology. He defined it simply as a "plan of procedure by a decision-making unit". ${ }^{\mathrm{I}}$ No-one will raise objections to this definition when we think only of individuals. Obviously, the real

I. Fredrik Barth, Process and Form in Social Life (London [etc.], I981), p. 98. 
problems begin when we move on to the family as the "decision-making unit" and start talking about "family strategies". Indeed, the term "family strategies" has been used for a variety of topics. One field of research are the truly collective strategies aiming at maximizing and securing family income, e.g. in the case of members working in different occupations to reduce the risk of unemployment. ${ }^{2}$ In other studies parental strategies are the centre of interest, either in an altruistic or a nonaltruistic sense. An example of the first may be found in the strategies of wealth accumulation by parents intended to make bequests to their children. ${ }^{3}$ An example of the latter are decisions taken without any regard to the children's interest. For instance, Chinese fathers often gave their "useless" daughters away for adoption at a very tender age. ${ }^{4}$ Finally, the family can be seen as the playground in which individual family members enter into negotiations not necessarily on an equal basis - to further their own goals. An example are the negotiations between family members regarding the question of care for the parents in old age. 5 At this stage, choosing a particular definition of "family strategy" is not very useful. It remains to be seen to what extent individual family members collaborated in joint decisions and why they did so. Obviously, the relative weights of the collective unit, the parents and the individual children differed widely from one social group to another, from one period to another, and from one culture to another. In fact, establishing the leeway of individual versus parental or collective strategies is one of the challenges lying ahead of us.

\section{SYSTEMS, TRADITIONS AND RATIONAL ACTORS}

In his article, Engelen frequently opposes cultural norms, traditions, and "traditional lifestyles" on the one hand to strategy on the other. He believes that we cannot speak of strategy when a particular behaviour was apparently inspired by tradition. In my opinion, this opposition is not helpful in understanding day-to-day decisions. It is unrealistic to assume that people will make a complex cost-benefit analysis of every choice they are faced with. Instead, they often follow the "algorithms of every day

2. J.H. Quataert, "Combining Agrarian and Industrial Livelihood: Rural Households in the Saxon Oberlausitz in the Nineteenth Century", Journal of Family History, Io (1985), pp. 145I62.

3. A. Mason and G. Tapinos (eds), Sharing the Wealth: Demographic Change and Economic Transfers Between Generations (Oxford, 2000).

4. A.P. Wolf and C. Huang, Marriage and Adoption in Chinese Society, I845-1945 (Stanford, CA, I980).

5. H. de Haan, In the Shadow of the Tree: Kinship, Property and Inheritance among Farm Families (Wageningen [etc.], I994); E. Bulder, The Social Economics of Old Age: Strategies to Maintain Income in Later Life in the Netherlands I880-1940 (Amsterdam, 1993). 
life". 6 They do so precisely because they perceive from experience and example that this type of action suits their personal values best. No one expressed this point more clear than Fredrik Barth himself:

Generally, actors are guided by their own previous routines in similar situations, if they were not obviously disastrous, and by the approval and assurance obtained from others that a course of action is sensible. This usually means adopting a customary course of action. From a strategic point of view, this may in fact make rather good sense too: it reduces the need for information and enhances the predictability of outcomes [...].7

Another, perhaps more essential, aspect of Engelen's thinking on cultural norms is that he connects them to "mechanisms at the level of a society". He refers to the so-called "nuptiality valve" that is believed to have been operative in western Europe. Thanks to their pattern of late marriage and permanent celibacy, western European societies managed to keep population growth in check. The individuals themselves were probably unaware of the purpose of the normative system that underlaid their behaviour. Thus, they were "unconscious" of their own rational behaviour. The notion of "unconscious rationality" has been coined by E.A. Wrigley in his article "Fertility Strategy for the Individual and the Group". Wrigley believes that demographic imbalances, in particular a high level of mortality and a low level of fertility, will lead to the development of societal norms that will eventually restore the balance. $\mathrm{He}$ also believes that individuals will adhere to these norms, and thus act "rationally" in term of the group interests, even when this would go against their own interests. Wrigley models these individual interests in terms of heirship strategies. In view of the intergenerational transfers to be made, a father would be inclined to have a small number of children. ${ }^{8}$ In pre-industrial societies the "group", operating through social institutions and customs, managed to gear the behaviour of individuals towards corporate wellbeing.

My objections to Wrigley's ideas - and by extension to similar notions of "societal mechanisms" - are fourfold.

(I) It is even harder to avoid teleological reasoning than it is in the case of individual strategies. Wrigley himself was quite aware of this: "it tends to be demonstrable only ex post facto by its power of survival, which carries danger of circular argument". 9

(2) It is simplistic to assume that parents' calculations were guided only

6. Marcel van der Linden, "Conclusion", in Jan Kok (ed.), Rebellious Families: Household Strategies and Collective Action in the Nineteenth and Twentieth Centuries (Oxford [etc.], 2002), pp. 230-242, in particular p. 232.

7. Barth, Process and Form in Social Life, p. 100.

8. E.A. Wrigley, "Fertility Strategy for the Individual and the Group", in Charles Tilly (ed.), Historical Studies of Changing Fertility (Princeton, NJ, I978), pp. I35-I 54.

9. Ibid., p. I37. 
by the heirship motive. Security is often mentioned as an important reason for having children. Even in modern societies, having a child can be seen as a strategy to fortify a potentially unstable marriage. ${ }^{10}$ In the past, children offered an important form of social security for elderly parents. For instance, in Ireland the legal status of a widow improved enormously when there were children; only then could she inherit from her husband. Also, many widows used the dowries of their sons' brides for their own sustenance. ${ }^{\text {I I }}$ Obviously, these motives do not explain why one would like to have many children. Not restricting their fertility may have been a sensible policy for couples who could not be sure whether their children would survive the staggering infant and child mortality rates. High fertility was also related to the parents' awareness of alternative niches for their (redundant) children. ${ }^{\mathrm{I} 2}$ Finally, having a large number of children may have been advantageous to families who pooled labour, as in the case of farmers or proto-industrial workers, or who pooled wages. Wrigley did recognize this potentially positive effect of having a large family, but relegated the issue to "further study". ${ }^{13}$

(3) It is difficult to integrate change in notions of collective rationality. If people behave according to regulatory norms, how then do these norms, institutions, and customs themselves change? Wrigley appears to take an evolutionary position, when he writes that groups that limit their fertility will be replaced "by a population [...] not so inhibited". ${ }^{\mathrm{I} 4}$ But how did the reverse movement, that is from high to low fertility occur, if people themselves did not perceive the rationality of smaller family size? In the remainder of this section as well as in the next, more attention will be given to the issue of behavioural innovation.

(4) Finally, theories assuming regulatory mechanisms at the macro level tend to confuse levels of explanation. Frequently, observations of trends on the national or the regional aggregate or macro level are used to explain

ıo. D. Friedman, M. Hechter, and S. Kanazawa, "Theories of the Value of Children: A New Approach", in R. Leete (ed.), Dynamics of Values in Fertility Change (Oxford, 1999), pp. 19-47, in particular pp. $26 \mathrm{ff}$.

I I. J. Bourke, "Avoiding Poverty: Strategies for Women in Rural Ireland, I880-1914", in J. Henderson and R. Wall (eds), Poor Women and Children in the European Past (London, 1994), pp. 28-3 I I, in particular pp. 303-304. See also W.A. Sundstrom and P.A. David, "Old Age Security Motives, Labour Markets and Farm Family Fertility in Antebellum America”, Explorations in Economic History, 25 (1988), pp. 164-197, in particular p. 179.

I2. D. Levine, At the Dawn of Modernity: Biology, Culture, and Material Life in Europe after the Year 1000 (Berkeley, CA [etc.], 200I), pp. 285-286; S. Szreter and E. Garrett, "Reproduction, Compositional Demography, and Economic Growth: Family Planning in England Long before the Fertility Decline”, Population and Development Review, 26 (2000), pp. 45-80, in particular pp. 54-55.

I3. Wrigley, "Fertility Strategy", pp. I47-I48.

I4. Ibid., p. I49. 
behaviour on the level of the individual. ${ }^{\text {Is }}$ In their highly influential Population History of England, Wrigley and Schofield compared longterm trends in English living standards with aggregate data on nuptiality and fertility, and concluded that the preindustrial demographic regime of prudential marriage was intact at least until the mid-nineteenth century. ${ }^{16}$ However, disaggregation of the English demographic data of the nineteenth century reveals that there were strong and increasing differences in demographic behaviour between social groups, differences obscured by the general trends. The middle classes, the rural poor and the urban workers all displayed distinct patterns of nuptiality and fertility. ${ }^{17}$

Wrigley states that the core of the demographic transition was the "change from a system of control through social institution and custom to one in which private choice of individual couples played a major part in governing the fertility rate". ${ }^{18}$ In other words, in most pre-industrial societies, France being a notable exception, marital fertility was beyond the range of conscious planning. Generally, conscious fertility regulation has been equated with "stopping" when a desired number of children was reached. Obviously, this "parity-specific" control can be applied efficiently only through the use of modern contraceptive devices, which did not become widespread before the twentieth century. However, this conventional wisdom is being challenged by research using new techniques. These studies call attention to the phenomenon of "spacing", that is lengthening the intervals between subsequent births or even between marriage and the first birth (also called "starting"). Spacing appears to have been a much more important facet of fertility than has previously been assumed. ${ }^{19}$ The present discussion on the subject is on the extent to which spacing and starting were consequences of physiological processes or, on the other hand, indicators of rational interventions. A physical cause of the observed fertility patterns may have been malnutrition. For instance, the alleged practice of "late starting" among Chinese women, who often married in their teens, may be ascribed to delayed menarche due to the

I s. This problem is discussed by Theo Engelen in his "Family, Production and Reproduction: on the Relationship between Economic and Demographic Processes", Economic and Social History in the Netherlands, 6 (1994), pp. 61-82, in particular pp. 71-72.

I6. E.A. Wrigley and R.S. Schofield, The Population History of England I54I-I87I: A Reconstruction (Cambridge, 1989).

17. S. Szreter and E. Garrett, "Reproduction, Compositional Demography, and Economic Growth", in D. Levine, Reproducing Families: The Political Economy of English Population History (Cambridge, 1987), pp. i 8 , I30.

I8. Wrigley, "Fertility Strategy", p. I 48.

19. See, for example, D.L. Anderton and L.L. Bean, "Birth Spacing and Fertility Limitation: A Behavioral Analysis of a Nineteenth Century Frontier Population”, Demography, 22 (1985), pp. 169-183; V. Hionidou, "The Adoption of Fertility Control on Mykonos I879-1959: Stopping, Spacing or Both?”, Population Studies, 52 (1998), pp. 67-83. 
deprivations suffered by many Chinese children. ${ }^{20}$ Also, the practice of breast-feeding had the effect of lengthening intervals, whereas coital frequencies of marriage partners may have been low because of seasonal migration. In other words, we cannot conclude automatically that deliberate fertility strategies were employed on the basis of long birth intervals alone.

However, a number of recent studies manage to detect conscious planning in spacing behaviour. An important work in this respect is Szreter's Fertility, Class and Gender in Britain. ${ }^{21}$ In a reanalysis of the British fertility census of I9I I, Szreter shows that relative low fertility was achieved early in marriage, and often in combination with a high age at marriage. Spacing by means of low coital frequency in combination with coitus interruptus, was the principal means of - deliberate - birth control. Therefore, the decline of marital fertility was not an innovation based on new techniques, but the intensified use of traditional methods deeply ingrained in British culture. Sexual self-control, amounting to abstinence within marriage, was, well into the twentieth century, the norm among upper and lower classes alike. In fact, sexual restraint within marriage was in line with the obvious restraint practised by late-marrying couples before marriage. ${ }^{22}$ According to Szreter, fertility varies between social groups and periods because of differences in the perceived relative costs of childrearing. The costs and benefits are not to be understood in financial terms alone, because emotional and cultural aspects are of similar importance. Whether altered perceptions will be translated into new family building strategies is dependent on the relationship between spouses, which is strongly influenced by gender division, particularly in the labour market. For instance, the low marital fertility of textile workers is linked to the importance of female and child employment in this sector. Because of the wife's contribution to the family income, it was vital that she was not encumbered with too many births early in marriage. According to Szreter, the relative equality of gender work roles was a crucial prerequisite for successfully negotiated fertility reduction. Occupational variation in fertility was strongly related to the factor "community". Particularly in the working classes, local communities formed the "information contexts" that guided behaviour. Within communities, couples were able to observe

20. A.P. Wolf, "Is There Evidence of Birth Control in Late Imperial China?", Population and Development Review, 27 (200I), p.I40. Wolf's article was directed, among others, against J.Z. Lee and C.D. Campbell, Fate and Fortune in Rural China: Social Organization and Population Behaviour in Liaoning, 1774-I883 (Cambridge, I997); and J.Z. Lee and W. Feng, One Quarter of Humanity: Malthusian Mythology and Chinese Realities (Cambridge, 1999). See also J.Z. Lee and W. Feng, "Malthusian Models and Chinese Realities: The Chinese Demographic System 1700-2000", Population and Development Review, 24 (1998), pp. 33-65.

21. S. Szreter, Fertility, Class and Gender in Britain I860-1940 (Cambridge, 1996).

22. E. Garret, A. Reid, K. Schürer, and S. Szreter, Changing Family Size in England and Wales: Place, Class and Demography, I89I-I9II (Cambridge, 200I), p. 43 I. 
the relative benefits of larger or smaller families among their peers. They then "would have begun gradually to modify their sexual and reproductive behaviour towards their new perceived optima. This occurred almost regardless of extant prescriptive norms, as a set of relatively independently taken 'private' decisions. Collective, publicly articulated norms were then renegotiated at a later stage $[\ldots]$ ". ${ }^{23}$

A recent empirical test of Szreter's ideas has been performed by Van Bavel in a longitudinal cohort study of the Belgian city of Louvain. ${ }^{24}$ Not only could he prove that already birth cohorts of women born before i 850 practised spacing in function of the number of dependent children, he also showed how this was related to women's work. Women who could not combine (too many) small children with their employment, tended towards larger birth intervals. As elsewhere, spacing preceded stopping, which was a more effective means of fertility reduction. In Louvain, the innovation of stopping was associated with French-speaking inhabitants. In addition, Van Bavel discloses highly interesting patterns on the level of the neighbourhood. Couples living in ethnically or socially mixed neighbourhoods tended to adopt stopping earlier than couples living in homogeneous neighbourhoods. ${ }^{25}$ This finding is in line with other studies showing that strong and homogeneous local networks have a tendency to delay the adoption of innovative behaviour. ${ }^{26}$

In short, the notion of "unconscious rationality" emanating from traditions or mechanisms at the level of society appears to have a shaky theoretical and empirical basis, at least in the field of fertility control. Historical actors did consciously influence the size of their families. How "strategic" can this be called? Lynch and Viazzo describe Szreter's model of fertility decline in terms of a customary "adaptive rationality" providing the basis for the eventual "invention and elaboration of individually-based and fully conscious strategies". In my opinion, it is not very useful to distinguish between rational adaptation on the one hand, and innovative strategies on the other. Innovation of behaviour, the root of social change, seems to be a very gradual process in which people, starting out from their experiences, customs, and norms, perceive that a particular solutions of significant others - often their neighbours - is more effective than their own. They then experiment with this behaviour themselves, until their adaptation is taken over by many persons and social change on the

23. Szreter, Fertility, Class and Gender, p. 557.

24. J. van Bavel, Demografische reproductie en sociale evolutie: Geboortebeperking in Leuven I846-I9I0 (Leuven, 200I).

25. Ibid., pp. 34I, 348 .

26. M. Granovetter, "The Strength of Weak Ties", American Journal of Sociology, 78 (1973), pp. I360-I380. The inhibiting effect of strong networks on the perception of extra-local opportunities has been demonstrated also by P.-A. Rosental, Les sentiers invisibles. Espaces, familles et migrations dans la France du I9e siècle (Paris, I999), p. 2 Iо. 
aggregate level occurs. Obviously, this aggregate change posits new problems and challenges for the individual actors, propelling the cycle of micro-macro interaction on. ${ }^{27}$

\section{WHAT IS WRONG WITH INFERRING STRATEGIES?}

According to Engelen, Lynch and Viazzo, and many other critics as well, the real problem of the strategy concept lies in its operationalization in historiography. The methodological obstacles that are frequently mentioned are the following. (I) Knowing a persons' "strategy" implies knowing his or her motives. Since motives can be cultural as well as economical, we actually need to know the personal "values" of the historical actors. (2) To reconstruct a particular strategy, we need to know the limitations or constraints that were placed on the person by his or her environment as well as (3) the various behavioural options that were available at any given time. (4) To understand the process of decisionmaking, we also need to know the quality of information that the actors possessed. It is difficult to assume effective planning under conditions of inadequate information on risks and opportunities. ( 5 ) Clearly, most historical sources cannot meet these demands. Given the paucity of data on motives, constraints, options, and information, strategies tend to be inferred only from behavioural outcomes. In this sense, use of the concept actually threatens to obscure instead of elucidate the chains of human action and reaction.

Indeed, quite a number of historical studies on strategies have failed to overcome these obstacles. Can these problems be surmounted at all? The methodological difficulties germane to "strategy" were discussed extensively by Moen and Wethington in their critical 1992 article. However, they concluded by advocating the life-course approach as a way of steering the concept through its methodological minefield. ${ }^{28}$ The life-course approach is a device to study the interaction between individual lives and social change. The life course can be defined as the sequence of positions of a particular person in the course of time. A position can be either marital status, parenthood, employment etc. A life-course analysis studies the frequencies and the timing of changes in positions, generally of groups such as birth cohorts. These changes are called events or transitions. Every life course is characterized by a sequence and combination of transitions, such as leaving home, finding work, finding a partner, and becoming a parent. Timing is a central concept in the life-course approach. In making transitions, individuals not only have to take account of their

27. P.-A. Rosental, “Construire le 'macro' par le 'micro': Fredrik Barth et la microstoria”, in J. Revel (ed.), Jeux d'échelles. La micro-analyse à l'experience (Paris, 1996), pp. I4I-I 59.

28. P. Moen and E. Wethington, "The Concept of Family Adaptive Strategies", Annual Review of Sociology, i 8 (1992), pp. 233-25 I. 
own age, aims, and opportunities, but also on those of others in their environment. Thus, lives are seen as interdependent. Indeed in the past, the economic situation of the family was decisive in determining whether and when particular persons could study, leave home, or marry. On another level, life courses are influenced by historical time, that is, by upheavals such as a war, by economic cycles, or by the gradual shift in social norms. The particular stage in their lives in which people experience historical developments has an impact on their behavioural choices, also later on in the life course. Thus, there is a cumulative effect of past experiences framing current conditions and choices. ${ }^{29}$ Life-course analysis appears particularly suitable for the study of family strategies. Since time itself is the dependent variable, the approach is essentially dynamic. The cohesion in the timing of the transitions of family members concerning work, fertility and migration, may reveal the extent of family coordination. In the words of Modell and Hareven: "The examination of timing can, at least, provide insights into internal processes of family decision making". ${ }^{\circ}$ Finally, families are not conceived of as autonomously acting units. The focus is on the individual - in the framework of the family..$^{31}$

Adopting a life-course approach not only means that (groups of) individuals have to be traced in all their major transitions, it also requires knowledge on their constantly changing context: the situation of their family, and of their place of residence, as well as the specific historical circumstances. The ideal solution is longitudinal cohort studies that take account of a large number of variables pertaining to individuals, their households, and their surroundings. In other words, not only the timing and sequences of actions of the individuals have to be known, but also their "structural" constraints in any particular moment. Fortunately, an increasing number of historical databases are being constructed that approach this ideal. ${ }^{2}$

29. G. Elder, Children of the Great Depression (Chicago, IL, I974); T.K. Hareven, Family Time and Industrial Time: The Relationship between the Family and Work in a New England Industrial Community (Cambridge, 1982); idem, Families, History and Social Change: Life Course and Cross-Cultural Perspectives (Boulder, CO [etc.], 2000).

30. J. Modell and T.K. Hareven, "Transitions: Patterns of Timing", in T.K. Hareven (ed.), Transitions: The Family and the Life Course in Historical Perspective (New York, 1978), pp. $245-269$, in particular p. 248 .

31. J. Kok, "Revealing Family Strategies Using Life-Course Analysis", Economic and Social History of the Netherlands, 6 (1994), pp. 109-I27, in particular p. I I3.

32. See the databases described in Patricia Kelly Hall et al. (eds), Handbook of International Historical Microdata for Population Research (Minneapolis, MN, 2000). Other examples are found in G. Alter, Family and the Female Life Course: The Women of Verviers, Belgium, I849I880 (Madison, WI, I988); D.I. Kertzer and D.P. Hogan, Family, Political and Demographic Change: The Transformation of Life in Casalecchio, Italy, I86I-I92I (Madison, WI, I989); J. Dupâquier and D. Kessler, La société française au xix siècle. Tradition, transition, transformations (n.p., 1992); Lee and Campbell, Fate and Fortune. 
Let us return to our basic question: can these data-sets solve the problems intrinsic to the strategy concept? Obviously, a collection of individual transitions does not directly reveal individual motives, let alone culturally based aims and values. However, we can at least minimize this problem by comparing the behaviour of people from the same cultural and social background. By analysing the (variation in) the ways they responded to changing opportunities or to crisis situations, we can detect the strategic element in their behaviour. Controlling for constraints, we can try to reconstruct their options. It should be emphasized that people are never devoid of choices. In his article, Engelen portrays rural labourers as "victims of structural poverty", and peasants as having no "alternative options except the actual behaviour we find". Concerning this point, Fredrik Barth made the astute remark:

No matter what rhetoric sometimes tells us, choice is not synonymous with freedom, and men and women rarely make choices under circumstances chosen by themselves. What is more, the unfortunate circumstance of a gross disadvantage of power does not mean that strategy is unavailing - indeed it may be all the more essential to the actor and all the more pervasive in shaping his behaviour. ${ }^{33}$

Rural labourers, for instance, facing a declining income, can opt to intensify the labour participation of their family, seek employment in a city or emigrate to a country were agriculture still holds promises. In this sense, the concept of strategy is basically a hypothetical construct used for modelling combinations and sequences of decisions. ${ }^{34}$ The problem of information can be dealt with by introducing appropriate variables into the models. For instance, the level of schooling can be used as a proxy for the amount of reliable information a person is likely to acquire on opportunities in distant areas. Also, information often reaches a person through his personal network. It is likely that socially and geographically diversified networks have the capacity to convey the type of information that incites behavioural change. Proxies for personal networks can be found in migration experience of the individual and members of his family, but sometimes genealogies provide information on the wider kinship networks. ${ }^{35}$ Finally, how can we detect strategies in the actual behavioural outcomes? There are two ways of approaching this issue. Firstly, we can

33. Barth, Process and Form in Social Life, p. 89.

34. L. Fontaine and J. Schlumbohm (eds), "Household Strategies for Survival I600-2000:

Fission, Faction and Cooperation", International Review of Social History, 45 (2000) supplement 8, pp. I-I7, in particular p. 6.

35. M. Gribaudi, Itinéraires ouvriers. Espaces et groupes socianx à Turin au début du XX $X^{\mathrm{e}}$ siècle (Paris, 1987); P.-A. Rosental, Les sentiers invisibles. Espace, familles et migrations dans la France $d$ u $19^{\mathrm{e}}$ siècle (Paris, 1999). 
determine to what extent people conformed to the courses of action we hypothesized beforehand. ${ }^{36}$ This may include behaving in customary and socially approved ways, which, as we have seen, can be a rational strategy as well. Secondly, we can concentrate on those truly innovative individuals who choose different, new options. What were the particular backgrounds and experiences that made them into "pioneers"? To what extent and by which processes was their example adopted by others? 37

Although Lynch and Viazzo note that strategies may only be observed "by adopting a longitudinal perspective", they do not discuss examples of this approach. Engelen, however, devotes a lengthy part of his article in discussing an empirical study of family labour strategies by four Dutch and Belgian historians. My colleague Richard Paping and myself based our case studies on longitudinal cohort analyses in respectively the Dutch provinces of Groningen and Utrecht in the nineteenth and early twentieth centuries. Engelen concludes firstly that these studies have provided few insights in the actual strategies of the families whose occupations and migrations were analysed. ${ }^{3}$ Secondly, he surmises that this means that the concept of strategy is too problematic to be used in empirical research. I tend to agree, but only with the first conclusion. Looking back, it is easy to see the methodological choices that would have resulted in a more convincing "test" of the strategy concept. Firstly, we appear to have cast our nets too wide. We included various social groups from broad areas and long periods in our analyses. The drawback of the data-sets used was that too few individuals were available to study the behavioural responses of persons from the same age and social position to the same historical conditions. Not being able to control for backgrounds and constraints, our hypotheses on aims and strategies were too vague. Most importantly, by concentrating exclusively on labour and migration strategies we neglected to look for alternative options. Instead of changing occupation or residence, people may have chosen to rely on poor relief, invest in land, take in boarders etc.

Explanations of historical processes generally assume the form of hypothetical models of cause and result. These models often improve by adopting assumptions on decision-making in the context of families. For instance, studies on migration, both historical and contemporary, show the greater explanatory value of "family models" in relation to models including

36. Bulder, The Social Economics.

37. J.Z. Giele, "Innovation in the Typical Life Course", in J.Z. Giele and G.H. Elder (eds), Methods of Life Course Research: Qualitative and Quantitative Approaches (Thousand Oaks, CA, I998), pp. 23 I-263.

38. J. Kok, "Choices and Constraints in the Migration of Families: The Central Netherlands, I $850-1940$ ", and R. Paping, "Family Strategies Concerning Migration and Occupations of Children in a Market-Oriented Agricultural Economy", History of the Family: An International Quarterly, (2002), forthcoming. 
only individuals responding to regional economic changes. ${ }^{39}$ These family models hypothesize actions of family members in relation to their constraints, their options, their information, and the behaviour and interests of other family members. On condition that such models are built carefully and tested rigorously, there is nothing wrong with inferring strategies.

\section{LEAVING HOME: WHO IS THE STRATEGIST?}

Although it is possible to build models that incorporate constraints, choices and information, we still need to know whose aims and interests are served by a particular course of action. This means that we have to take account of the power relations between the sexes and the generations within the family as well as of the possibility of negotiation between the family members. This implies that qualitative information on family structures and intergenerational relations is indispensable in constructing our hypotheses. Contrary to what Engelen, Viazzo, and Lynch seem to advocate, this does not mean that we need "direct" insight in the actual intentions of the historical actors themselves. In fact, knowing those individual motives may not solve our problems. Even those rare studies that enable one to compare motives and subsequent behaviour show that there are not always direct links. For example, in a recent panel study of Thai households, respondents were questioned on their intentions of migrating in the near future. Two years later, the actual moves of the respondents could be contrasted with their original plans. The outcomes show that individual intentions were not directly related to (future) migration behaviour. The crucial factors in the actual migration decisions appeared to be norms and interactions on the level of the family..$^{\circ}$

The problems and potentialities of modelling strategies can be illustrated by the topic of leaving home in a pre-industrial setting. Both individual and collective considerations are involved in the institution of service in other households. Removed from direct parental control, individuals may have saved money, acquired new skills, and met future spouses. In other words, this experience may have been a valuable asset for the future. On the other hand, parents may have sent their children to live in another household simply because it was less costly and even brought in some extra income. Is it possible to distinguish short-term from long-term motives, and individual from parental strategies? Engelen denies this, and uses the subject to demonstrate the limits of the strategy concept. In his article, he discusses

39. C. Pooley and J. Turnbull, Migration and Mobility in Britain Since the Eighteenth Century (London [etc.], 1998), pp. I9I-192; G.F. DeJong, "Expectations, Gender, and Norms in Migration Decision-making”, Population Studies, 54 (2000), pp. 307-31 9; J. Lauby and O. Stark, "Individual Migration as a Family Strategy: Young Women in the Philippines", Population Studies, 42 (1988), pp. 473-486.

40. DeJong, "Expectations, Gender, and Norms", p. 3 I7. 
Paping's study of leaving home in the Groningen clay area. Paping compared the occupational positions after marriage of former farm servants with the positions of individuals who had stayed at home. He demonstrated that the experience of domestic service was not conducive to upward social mobility. In fact, it often formed the prelude to downward mobility. From this outcome, Paping concludes that the service of children must have served short-term (economic) goals of the family, e.g. relieving the family of an extra mouth to feed. Secondly, he surmises that only a small number of parents could afford to invest in their children's future, by letting them stay at home. By I900, this proportion had become considerably larger, due to the improved financial situation of the areas' working class. Engelen rejects these conclusions for three reasons. Firstly, because the outcomes are projected on the original intentions. Parents may have had the original wish to invest in their children's future but simply lacked the information that this was not successful. Secondly, because the motives of the children and their bargain with the parents are not dealt with in Paping's discussion on service. Finally, because the mechanism of selecting children to leave or stay remains unclear. Particular children may have remained at home, not because their parents decided it would be the best option for their future, but because the family composition at the time they reached age fifteen required them to work at home. Engelen concludes that the strategy concept itself is responsible for the unconvincing results. However, I would like to argue that more elaborate procedures and appropriate data-sets enable us to analyse leaving home from both the perspective of the family and the motives of the adolescents themselves.

First of all, the experience of service should be treated as the complex phenomenon it is. A prerequisite for understanding the impact of service on the future life course is the careful analysis of its manifestations. This means that the length of stays in other households should be determined, as well as the frequency of return moves to the parents. More important, we need to reconstruct the social and geographical trajectories of the servants. The first are indicated by the social status of their masters and the latter by the migratory moves made from one job to another. Possibly, those servants who moved from rural to urban locations and from masters with lower status to masters with higher status, were able to realize upward mobility themselves. The timing of leaving home is of crucial importance. It is precisely here that we can detect both the way in which expelling children was a response to the imminent economic needs of the family and the way in which decisions regarding an individual child were synchronized with those of other family members. ${ }^{41}$

4I. T.K. Hareven and K. Adams, "Leaving Home: Individual or Family Strategies", in J.Z. Lee, M. Oris, and F. Van Poppel (eds), The Road to Independence: Leavers and Stayers in the Household in Europe (Bern, 2003, forthcoming). 
In two recent dissertations, leaving home is analysed using elaborately designed models. In the study by Hilde Bras, the life courses of women from the Dutch province of Zeeland are analysed for the period I $850-$ I950.42 The author concentrates on the family backgrounds of domestic service. The synchronization of events and decisions is studied with a technique called event-history analysis. ${ }^{43}$ Bras describes the trajectories of the servants and relates them to their social mobility, indicated by their own occupational careers and the social status of their marriage partners. However, she sets out by analysing qualitative evidence on the decisionmaking process. Diaries, letters, and interviews with former domestic servants from the area reveal that, predominantly, the parents decided that particular daughters had to enter service. Generally, they were to hand over their earnings to the parents. Many interviewed women regretted this decision, but some indicated that the alternative (having to take care of the elderly parents) was even worse. Statistical analysis shows that the timing of leaving home was clearly related to the family's needs. When one of the parents had died, a girl would enter service sooner. Also, older girls with younger sisters were often sent away. An oldest girl became adolescent during a stage in the family life cycle when extra income was badly needed. When her household chores could be done by younger sisters, she could become a servant. Bras shows that more than one-third of all Zeeland women had worked as a domestic servant, on average for about five years. Generally, this experience was not instrumental in finding "higher" occupations or "better" marriage partners. Interestingly, servant girls that migrated out of the province to urban destinations did experience upward mobility. Is this an example of pioneering girls following their own strategy? Bras relates their trajectory to family characteristics, such as the father's social position and the parental network. In other words, some families possessed the necessary information and resources to let their daughters migrate and work in a position that offered prospects. This study shows that the motives of persons can be reconstructed using qualitative evidence from other persons, provided they share basic characteristics. This information is then used to construct explanatory models. In testing these models, individual transitions are related to the dynamically evolving family situation. Life courses - in the sense of geographical and social trajectories - are studied in their full diversity. In doing so, the cumulative impact of diverse experiences on the "outcomes", in this case the social position at marriage, can be assessed. Finally, it is possible to evaluate the role of "family strategies" in leaving home. Both

42. H. Bras, Zeeuwse meiden. Dienen in de levensloop van vrouwen, ca. 1850-1950 (Amsterdam, 2002).

43. See Alter, Family and the Female Life Course; P.D. Allison, Event History Analysis: Regression for Longitudinal Event Data (Thousand Oaks, CA [etc.], I984). 
qualitative and quantitative evidence suggest that sending a girl into service stemmed from the need to balance the household budget. Neither the employments themselves, nor the patterns of their succession, indicate a conscious wish for social improvement. Only for a small group of middleclass girls was domestic service related to parental investment in their future.

Another impressive study on (farm) service is Martin Dribe's dissertation on leaving home in southern Sweden (I829-I866).44 This study analyses how agrarian households responded to demographic and economic crisis situations by retaining or expelling their adolescent children. This is done by applying event-history techniques to the very rich Swedish data on households. Dribe assumes that the skills of the children and their subjection to parental authority differed by age. Therefore, he makes separate models for children aged ten to sixteen and adolescents/adults aged seventeen to thirty. In particular, younger children tended to leave families with unfavourable dependency ratios. Also, their leaving home was affected more strongly by price fluctuations. As in Zeeland, sending children away was one of the strategies of a widowed parent. Economic fluctuations, measured by harvest outcomes and grain prices, had differing effects on different households. Peasants responded to low prices by keeping children at home, thus economizing on wages paid to servants. Tenants on noble estates tended to keep their (older) children at home when the harvest had been good. In this way they responded to the increased demand for labour. The children could supplement family income by working on the estates or on the tenants' land. Among the landless workers, leaving home at an early age was so common that the timing itself could not be used as a "strategy of consumption smoothing in times of economic stress". 45

Both studies show that leaving home was quite strongly related to shortterm household interests. In doing so, they also make it plausible that, at least for most social groups in the past, service was not intended to boost the careers of individual children. The leeway of individual strategies versus parental strategies appears to have been restricted, in particular for younger children.

\section{THE SCOPE OF STRATEGY}

If we recognize the rational character of (most) patterned behaviour, we can assume that an element of planning is practically always present. In

44. M. Dribe, Leaving Home in a Peasant Society: Economic Fluctuations, Household Dynamics and Youth Migration in Southern Sweden, I 829-I 866 (Södertalje, 2000).

45. Idem, "Leaving Home as a Family Strategy in Times of Economic and Demographic Stress: The Case of Rural Scania, Sweden I829-1866", in Lee, Oris, and Van Poppel, The Road to Independence. 
other words, the strategy concept can also apply to the multitudinous ways of sustaining a family and of improving one's lot. I have no objections to calling these short-range strategies "tactics" - as proposed by Lynch and Viazzo - as long as we take them serious in our research. In particular, we need to study how "tactical" choices create the conditions that either block or enhance the realization of strategies for the long term. Another field of interest is the way in which combinations of tactics are chosen and changed. In this section, I will sketch the possibilities and implications of research in this field.

Indeed, "tactics" is an apt term to describe the daily efforts of families to cope with the insecurity that threatened them in many ways. For instance, urban wage workers could deal with depressed wages or unemployment by applying for poor relief, pawning their possessions, economizing on the budget by moving to a cheaper lodgings, taking in boarders etc. ${ }^{46}$ However, we should not be misled by their commonness and the short range of the planning involved. Choosing particular tactics can have had far-reaching consequences, extending even to the next generation. Often, emigration is seen as the prototypical example of a long-term strategy, since it required information, planning, and (accumulated) resources. However, in many cases emigration was a trial-and-error tactic. For instance, in I 889 hundreds of destitute Frisians left for Argentina, for the sole reason that the Argentinian government offered them free transport. However, the next year, when the misfortunes of the settlers became known, practically no one followed their example. ${ }^{47}$ Obviously, emigration determined to a large extent the future opportunities of both individuals and their children. Another example of a "tactic" with lasting effects are the land sales eighteenth-century French wine-growers were forced to make when an economic slump coincided with an unfavourable stage in their family cycle. This led to strong and irreversible wealth differences with other farmers who could accumulate land thanks to more favourable family circumstances. $4^{8}$

Although often imbedded in customs or habitus, tactics are rational and

46. B. Bradbury, "Pigs, Cows and Boarders: Non-Wage Forms of Survival among Montreal Families, I86I-91", Labour/Le Travail, I4 (1984), pp. 9-46; A.G. Hunter, "Making a Way: Strategies of Southern Urban African-American Families, I900 and 1936", Journal of Family History, I 8 (1993), pp. 23 I-248; R.V. Robinson, "Family Economic Strategies in Nineteenth and Early Twentieth-Century Indianapolis", Journal of Family History, 20 (1995), pp. I-22; J. Kok, K. Mandemakers, and H. Wals, "City Nomads: Moving House as a Coping Strategy, Amsterdam 1890-1940", unpublished paper for the Fourth European Social Science History Conference, The Hague, 27 February-2 March 2002.

47. H. de Vries, Landbouw en bevolking tijdens de agrarische depressie in Friesland (I878-1895) (Wageningen, 1971), p. I 85 . See also Paping, "Family Strategies Concerning Migration".

48. G. Béaur, "Land Accumulation, Life Course, and Inequalities among Generations in Eighteenth-Century France: The Winegrowers from the Chartres Region", History of the Family, 3 (1998), pp. $285-302$. 
conscious methods of solving problems. This means that people can and will drop fruitless tactics and adopt promising new ones. In this way, successful new tactics can spread rapidly in a population. It will be a challenge for future research to study the conditions of "innovation" in tactics. For instance, Fontaine and Schlumbohm point to the conditions (geographical location, resources, and network) that enable people to shift from pure subsistence activities to commercial activities, "thereby providing access to another sphere of risk and anticipation". 49

Seemingly, households had a wide array of tactical options, but in fact the range was quite limited. A promising way of studying strategies is by delineating mutually exclusive combinations of tactics or "coping repertoires". Recently, Lex Heerma van Voss has proposed a classification of wage workers' strategies in three repertoires indicated as "loyalty", "exit", and "voice".5o "Loyalty" implies a continuous investment in both horizontal and vertical relations. Loyal (or deferential) workers invested in good relations with their neighbours, their church, their poor relief workers, and their patrons. For this option, a good reputation was a prerequisite. Their aim (or strategy) was to improve their lot by acquiring a plot of land or even a farm, for instance through a fortunate marriage. The "exit" option consisted of emigration. Finally, "voice" meant forfeiting good relations with social superiors by participating in some form of collective action. Heerma van Voss might have added a fourth repertoire, "crime". Several labouring families managed to survive by occasionally resorting to petty criminality such as pilfering or poaching. Some studies suggest that these families formed "subcultures" that were also characterized by sexual "deviance" such as illegitimacy and concubinage. ${ }^{\text {I }}$ Anyway, growing up in families of low repute must have severely limited the "loyalty" repertoire. According to Heerma van Voss, the success of collective options depended on their perceived relative benefits vis à vis the other repertoires. Greiff gives an example of this in his study of labour activism in Northern Ireland. Female textile workers in Belfast were prone to informal, direct action that was often successful. On the other hand, women textile workers in Lurgan massively joined the (male) trade union. The reason for this difference lies in the fact that Belfast women, in contrast with Lurgan women, relied on various sources of income and were not dependent on the strike funds administered by formal unions. ${ }^{52}$

49. Fontaine and Schlumbohm, "Introduction", p. I 2.

50. L. Heerma van Voss, Why Is There No Socialism in the Netherlands? De Nederlandse arbeidersklasse in de twintigste eeuw (Amsterdam, 2002), pp. I4ff.

5 I. V. Sleebe, "Van vader op zoon, van moeder op dochter? Familienetwerken en culture of poverty in Noord-Groningen", Tijdschrift voor Sociale Geschiedenis, 24 (1998), pp. I-30.

52. M. Greiff, "Marching Through The Streets Singing And Shouting': Industrial Struggle and

Trade Unions Among Female Linen Workers in Belfast and Lurgan, I872-1910", Saothar: Journal of the Irish Labour History Society, 22 (1997), pp. 29-44. 
Similar household-based calculations can be found among Dutch workers who weighed the costs of union membership against the benefits of the unions' direct offers, such as insurance. Interestingly, unions that advocated direct action, and thus were most damaging to one's reputation, were most popular among those unskilled workers for whom the "loyalty" repertoire never had been available. 53

The procedure for analysing short-term and long-term strategies is basically similar. In both cases the question is: does our understanding of behavioural patterns improve when we assume that people were guided by rational, strategic decision-making? To understand forms of collective protest, this means we assume that people rationally weighted the costs and benefits - in terms of respectability, risks, and income. However, there is a limit to the plausibility of our hypothetical constructions. Although it is likely that many people pursued plans for the distant future, it is harder to demonstrate these strategies, even with longitudinal datasets. Obviously, the capacity for successful planning diminishes with time. Notwithstanding all "strategic" measures taken, one simply cannot count on continuous security, health, and allegiance of friends and relatives. For instance, parents in East-Asian countries tried to maximize the pooled family income by sending children to (urban) areas with lucrative employment, but it proved difficult to secure their continued commitment. 54

In short, people are always planning, both on the short and the long range. Their plans for the future are constantly modified by "tactical" adaptations to new circumstances. Choosing particular options to deal with these circumstances may preclude other options, but it also may prepare the ground for entirely new, and unforeseen, sets of opportunities and constraints. Precisely this dynamic interplay between choices and constraints forms the heart of social history.

\section{CONCLUSION}

Admittedly, families strategies are difficult to implement convincingly in historical research. Why then should we persist in doing so? In his final paragraph, Engelen offers an alternative to the strategy concept. Because

53. H. Wals, "The Trade Union as Survival Strategy: The Case of Amsterdam Construction Workers in the First Quarter of the Twentieth Century", in Kok, Rebellious Families, pp. I40165 , in particular p. I58; J. Byrne, "Family and Unionisation in the Bricklaying Trade in Turnof-the-Century Madrid", in ibid., pp. 79-109.

54. D. Wang, "Stepping on Two Boats: Urban Strategies of Chinese Peasants and Their Children", in Fontaine and Schlumbohm (eds), Household Strategies for Survival, pp. 179-196, in particular p. 194. For an opposing view, see Y.-L. Lee, "Support between Rural Parents and Migrant Children in a Rapidly Industrializing Society: South Korea”, in Mason and Tapinos (eds), Sharing the Wealth, pp. 282-306. 
the reasons for individual behaviour are unknowable, we should be satisfied with reconstructing behavioural patterns of past populations. Without having to resort to explanations in terms of individual motives, we can distil "very interesting historical knowledge" from statistical trends. In my opinion, we should not stop at describing behavioural patterns but persevere in trying to explain them. As I have outlined above, explanations of behaviour in terms of mechanisms at the aggregate or macro level are quite unconvincing. We simply have to find out why people perceived a particular course of action as optimal. In Engelen's view, however, we walk straight into a heuristic dead end because we can never distinguish between constraints, strategies, and coincidence. When we only study strategies retrospectively on the basis of final results, he is quite right. However, longitudinal data-sets allow us to use history as an "experimental" social science. Hypotheses on strategic reactions of people faced with particular circumstances can be tested by tracing people in their successive variegated and interrelated decisions.

Generally, individual responses to societal changes are mediated by the family. To understand all kinds of behaviour, ranging from migration to collective action, we have to incorporate decision-making mechanisms at the level of the family. To zoom in on these mechanisms, we need information on (power) relations between generations and sexes, on the values of particular social groups and on their various options. However, we may infer the strategic goals, the bargaining positions of individual actors, and the action repertoire from qualitative evidence that is representative for the population in our quantitative data-sets. Our subsequent analysis will reveal how particular constraints are related to particular sets of behavioural outcomes. We can evaluate the effect of outcomes in terms of benefits for parents or children. We can see how family members timed their decisions in relation to one another. Also, experiences during the life course influenced cumulatively both constraints and options in later stages. Finally, our prospective analysis allows us to identify innovators who tried new solutions to common problems. The dissemination of their example forms the core of behavioural change at the aggregate level.

A rigorous test of hypotheses on family strategies requires longitudinal data-sets with information on the (dated) life events of individuals and their relatives. Furthermore, we need to place these individuals within an opportunity structure: e.g. what were the local sources of income, how did they evolve with respect to other areas? Finally, we need to know the information context of the individuals. Were they able to perceive and evaluate alternative options? Obviously, there are limits to this approach, in terms of data, time, and money, although an increasing number of projects are creating public access data-sets. More important, does this "rigorous" approach mean than other ways of studying family strategies 
are to be discouraged? Definitely not. As I have pointed out, it is essential to recognize the strategic options of individuals and their families, in order to make convincing models. Outcome-based studies can provide essential material for this elaboration.55 Therefore, studies that broaden our knowledge of families' adaptations are sorely needed. Also, Lynch and Viazzo rightly point out that much more qualitative information is needed on intrafamilial relations, as well as on the perceptions of these relations.

The challenge of future research on strategy lies first in the interaction of qualitative and quantitative approaches. Qualitative research provides the building material for complex models to be tested with longitudinal databases on life courses. In turn, they generate new questions that can only be answered with qualitative data. Second, using the family-strategies concept as a common tool will further the cooperation of family and labour historians. Family history has tended to ignore "collective" solutions for household problems. Conversely, the historiography of labour movements has often failed to see the household-based motives for and alternatives to collective action. Finally, strategies form a fascinating subject for intercultural comparative research. For example, to what extent did individuals perceive and develop their "own" courses of action with respect to marriage in the societies of Europe and Asia.? What determined the supposedly greater leeway in the choice of a partner and the timing of marriage in Western societies?5 "Strategy" will remain a central notion in social history and historical demography, not only because it is "appealing”, but because we can only gain by its further development.

55. G.H. Elder and L.A. Pellerin, "Linking History and Human Lives", in Giele and Elder, Methods of Life Course Research, pp. 264-294, in particular p. 27 I.

56. On daughters' strategies to resist arranged marriages in southern China, see J.E. Stockard, Daughters of the Canton Delta: Marriage Patterns and Economic Strategies in South China, I 860-I930 (Stanford, CA, I989). On the limits of medieval patriarchy in Europe, see Levine, At the Dawn of Modernity, pp. 288-324. On social and regional differentiation in individual and parental strategies, see J. Ehmer, "Marriage", in D.I. Kertzer and M. Barbagli (eds), The History of the European Family, volume 2: Family Life in the Long Nineteenth Century (New Haven, CT, 2002), pp. 282-32 I.On comparing marriage patterns, see M. Neven and C. Capron (eds), Family Structures, Demography and Population: A Comparison of Societies in Asia and Europe (Liège, 2000); M.J. Maynes and A. Waltner, "Women's Life-Cycle Transitions in a WorldHistorical Perspective: Comparing Marriage in China and Europe", Journal of Women's History, I 2 (2000), pp. I I-2 I; T. Engelen, F. Hendrickx, and A.P. Wolf (eds), Marriage and the Family in Eurasia: Perspectives on the Hajnal Hypothesis (Stanford, CA, 2002). 